\title{
Między etnocentryzmem a uniwersalizmem. Jak prowadzić dialog i szukać fundamentów globalnego porozumienia?
}

\section{KEY WORDS}

ethnocentrism, universalism cosmopolitanism, human rights

\begin{abstract}
Kalbarczyk Tomasz, Między etnocentryzmem a uniwersalizmem. Jak prowadzić dialog i szukać fundamentów globalnego porozumienia? [Ethnocentrism and Universalism. How to Hold a Dialogue and Look for Foundations for Global Understanding?]. Kultura - Społeczeństwo - Edukacja nr 1 (3) 2013, Poznań 2013, pp. 155-163, Adam Mickiewicz University Press. ISBN 978-83-2322631-4. ISSN 2300-0422

The paper refers to the discussion between different philosophical approaches to problems brought by globalisation. Building various concepts in social and political philosophy requires both rejecting radical relativism as well as finding alternatives to fundamentalism. Between radical approaches there is space for a reasonable ethics and theory of politics. I conclude with Wiktor Osiatyński's "soft universalism" of human rights, which can be deployed as a tool for building compromise between contradictory standpoints.
\end{abstract}

W artykule wymieniam kilka kontrowersji w ramach dyskusji między zwolennikami odmiennych stanowisk wobec problemów, które przynosi filozofii globalizacja, by jednocześnie pokazać możliwe płaszczyzny porozumienia oraz rozwiązania, które wpływają pozytywnie na kondycję współczesnej filozofii polityki. Jest to zaledwie przyczynek do badań rozległego tematu. Bardziej szczegółowo zajmuję się wątpliwościami dotyczącymi uzasadniania filozoficznych propozycji, tam bowiem znajduje się zwykle sedno sporu.

Niezmiennie istotna dla teorii sprawiedliwości i kosmopolitycznych idei, do których odnoszę się w niniejszym wywodzie, jest kwestia relatywizmu. Konstruowanie koncepcji w ramach filozofii społecznej i politycznej wymaga zarówno odparcia radykalnego relatywizmu, jak i znalezienia alternatyw wobec fundamentalizmu. Warto pokazać, że między skrajnymi stanowiskami znajduje się przestrzeń dla sensownej etyki i teorii polityki. 
W tekście odwołuję się do teorii praw człowieka, która jest zarówno pouczająca w kwestii polemik z radykalnym relatywizmem, jak i przynosi współcześnie pewne rozwiązania, które mogą konstruktywnie wpłynąć na opisywaną przeze mnie filozoficzną dyskusję. W konkluzji przedstawiam koncepcję „miękkiego uniwersalizmu” w ujęciu Wiktora Osiatyńskiego jako rozwiązanie umożliwiające budowanie kompromisu.

Martha Nussbaum, niewątpliwie jedna z najbardziej znanych i wpływowych osób utożsamiających się z kosmopolityzmem, opowiada się stanowczo za perspektywą uniwersalistyczną, odcinając się od relatywizmu, który często łączy się z promowaną przez kosmopolityzm wielokulturowością (Nussbaum, 1996)1. Atrakcyjny może być dla nas postulat autorki, by przyjąć koncepcję światowego obywatelstwa jako podstawę dla etyki oraz promować kosmopolityczne podejście do edukacji. Kontrowersyjna i, jak się zdaje, pochopna jest jej radykalna krytyka sceptycyzmu i wszelkich przejawów etnocentryzmu włącznie z specyficznym podejściem do partykularyzmu, które przyjął niegdyś Richard Rorty².

Być może rację ma Nussbaum, twierdząc, że wskazanie przez Rorty’ego kontrastu między polityką i edukacją opartą na rasowych, etnicznych i religijnych fundamentach oraz polityką i edukacją budowaną wokół narodowej, a raczej obywatelskiej identyfikacji, zawęża perspektywę. Zastanawiam się jednak, czy filozofka słusznie pisze, że Rorty nie dostrzegał możliwości znalezienia bardziej międzynarodowych podstaw dla polityki (Kalbarczyk, 2009: 4). Prowadząc refleksję nad pojęciami sprawiedliwości, lojalności i solidarności, rozważał filozof szerszą niż sąsiedzką czy narodową perspektywę. Co więcej, Rorty’emu zdarzało określać się jako internacjonalista, a jego postulat etyczny, by starać się maksymalnie zwiększać grupę ludzi, o których mówimy „my”, kosztem liczebności grupy, o której mówimy „oni”, nie jest niczym innym niż przykładem kosmopolitycznej etyki (Rorty, 2009b: 17, 288-302).

Odmienne perspektywy przyjmowane przez omawianych myślicieli zdają się zacierać podobieństwa widoczne niekiedy we wnioskach. Nussbaum twierdzi, że Rorty lekceważył wartości, które podzielają ludzie jako racjonalne i wzajemnie od siebie zależne istoty. Rorty zaś niechętnie podchodził do retoryki odwołującej się

${ }^{1}$ M. Nussbaum, Patriotism and Cosmopolitanizm [w:] For Love of Country. Debating the Limits of Patriotism Boston 1996. Książka zawiera tekst autorki oraz polemiki wybitnych filozofów współczesnych drukowane pierwotnie w „Boston Review”. Zob. również M. Nussbaum, W trosce o człowieczeństwo. Klasyczna obrona reformy kształcenia ogólnego, Wrocław 2008.

2 O sporze między Nussbaum a Rortym pisałem już w artykule: Wychowanie obywatelskie: między patriotyzmem a kosmopolityzmem, „Przegląd Filozoficzny” nr 1 (69), 2009, gdzie referowałem koncepcję wychowania kosmopolitycznego Nussbaum. W niniejszym tekście wracam do tego przykładu, ponieważ uważam, iż stanowi on spektakularny przykład sporu, gdzie filozoficzne podstawy oraz postawy autorów są diametralnie różne, ale wnioski wysnute przez interlokutorów zaskakująco sobie bliskie. 
do pojęcia racjonalności. Twierdził on, że nie powinniśmy przyjmować postawy: „Spójrzcie, o ile lepiej wiemy, jakie różnice między ludźmi są arbitralne, a jakie nie - o ileż bardziej jesteśmy racjonalni” (Rorty, 2009a: 98). Powinniśmy raczej mówić: „Oto jak żyjemy na Zachodzie w wyniku zniesienia niewolnictwa, podjęcia edukacji kobiet, oddzielenia Kościoła od państwa itd. Do tego doszliśmy, zacząwszy uznawać pewne rozróżnienia między ludźmi za arbitralne, a nie za mające znaczenie moralne. Jeśli spróbujecie owe różnice tak traktować, wyniki mogą wam się spodobać” (Rorty, 2009a: 98).

Nussbaum uważa, że, podobnie jak w czasach stoicyzmu, niezmiennie słuszne jest przekonanie, iż specyficznie ludzką cechą jest racjonalna potrzeba dążenia do sprawiedliwości, zachęca nas ona do traktowania na serio etyki Kanta. Jest wreszcie filozofka dosyć wierną uczennicą Johna Rawlsa ${ }^{3}$. Rorty zwykł podważać wiarę w ludzki rozum oraz uważał kantowskie podejście za nieaktualne - błędne oraz nazbyt optymistyczne. W kwestii prawa ludów Rawlsa filozof wyrażał zaś bardziej szczegółowe wątpliwości.

Za przejaw etnocentryzmu Rorty’ego można uznać jego podejście do dylematów, które stawiają przed nami procesy globalizacji. Pesymistyczna hipoteza zakłada, że demokratyczne wolności i instytucje mogą przetrwać tylko w warunkach osiąganej lokalnie gospodarczej pomyślności. Możemy się, według Rorty’ego, spodziewać, że pełna globalizacja rynku pracy, która prowadziłaby do zrównania płac robotników z obszarów dzisiejszego Pierwszego oraz Trzeciego Świata, oznaczałaby dla Zachodu koniec szeroko dostępnej edukacji, wolności słowa i innych instytucji, do których tak bardzo jesteśmy przyzwyczajeni (Rorty, 2009a: 82)4.

Czy bogate demokracje powinny bronić wolności i dobrobytu swoich mieszkańców kosztem reszty świata, czy poświęcić nasz styl życia dla globalnej, egalitarnej sprawiedliwości? Jest to dylemat moralny, wobec którego Rorty czuł się bezradny. Takie podejście jest nadmiernie pesymistyczne, a wręcz niedopuszczalne z punktu widzenia zdobywającego coraz większe uznanie utylitaryzmu Petera Singera. Autor Jednego Świata. Etyki globalizacji (Singer, 2006) dowodzi w swej pracy, że możemy zrobić znacznie więcej niż nam się wydaje, pozostawiając dla siebie wystarczająco wiele, jak i twierdzi, że jest to naszym moralnym obowiązkiem.

3 Rawls odcina się od kosmopolityzmu, choć jego próby rozszerzenia teorii sprawiedliwości poza państwa liberalno demokratyczne, podobnie jak fakt, iż prawo ludów jest teoretycznym rozwinięciem idei wiecznego pokoju Kanta, cieszy wielu kosmopolitów. Nussbaum zaś, budując swą wersję kosmopolityzmu, opiera się w pierwszym rzędzie na koncepcji zdolności A. Sena.

${ }^{4}$ Autor Przygodności, Ironii i Solidarności przywoływał również kwestię eksportu miejsc pracy. Niektórzy właściciele firm przenoszących swoje fabryki wypowiadali się w duchu kosmopolityzmu. Wiadomo, że opisywane zjawisko często łączy się z brutalnym wyzyskiem ludności Trzeciego Świata. $Z$ drugiej strony do zastanowienia nad innymi aspektami tego zjawiska skłania wypowiedź szefa dużego koncernu, który stwierdził: „jako człowiek oceniam ten proces pozytywnie. Nie uważam, za realistyczne, by 250 milionów Amerykanów kontrolowało tak wielką część światowego PKB”. 
Dominujący w związanej z globalizacją filozoficznej refleksji zdaje się być jednak nie utylitaryzm (choć stanowisko Singera jest niezwykle istotne), a liberalizm, ściślej rzecz biorąc liberalne teorie sprawiedliwości, w szczególności dyskusja nad teorią sprawiedliwości Rawlsa i jej rozszerzeniem poza państwa o ustroju demokracji konstytucyjnej. Kluczowy jest tu sukces liberalnego uzasadniania teorii sprawiedliwości, wolny od skrajności widocznych w libertarianizmie czy komunitaryzmie. Istotne jest również uznanie przez Rawlsa zapewnienia podstawowych praw człowieka jako pierwszej redystrybucyjnej konsekwencji prawa ludów.

Wątpliwości Rorty'ego budziły kryteria, które stosuje Rawls, próbując określić szersze ramy dla zastosowania teorii sprawiedliwości. Owe kryteria określają grupę nazywaną przez Rawlsa „przyzwoitymi społeczeństwami hierarchicznymi”, które to wraz z społeczeństwami liberalno-demokratycznymi tworzą społeczność ludów - przestrzeń, w której jest możliwe stosowanie wspólnych zasad (Rawls, 2001: 96-102). Pierwsze kryterium, które należy spełnić, by zasłużyć na miano przyzwoitego społeczeństwa hierarchicznego, to pokojowe postępowanie wobec innych społeczeństw, wyrzeczenie się agresywnych zamiarów w rozwiązywaniu problemów i napięć i środków wojennych na rzecz dyplomacji. Ekspansja jest dopuszczalna tylko w sferze kultury i handlu, obowiązuje respekt wobec politycznych i społecznych porządków w innych społeczeństwach.

Kryterium drugie jest złożone z trzech części. Po pierwsze, system prawny przyzwoitego społeczeństwa zabezpiecza przestrzeganie podstawowych praw człowieka. Rawls wymienia zestaw praw stanowiących absolutną podstawę: „prawo do życia (do środków egzystencji i bezpieczeństwa), do wolności (od niewolnictwa, poddaństwa, wymuszonej pracy oraz do wolności wyznania i myśli, wolności sumienia), do własności (własności osobistej), a także do formalnej równości wyrażonej przez reguły sprawiedliwości naturalnej (to znaczy do tego, by podobne przypadki były traktowane podobnie)" (Rawls, 2001: 97). Drugim elementem kryterium jest zdolność społeczności do działania na rzecz dobra wspólnego, a właściwie narzucania obowiązków związanych z funkcjonowaniem w społeczeństwie oraz moralnego rozwoju. Trzecia część kryterium „stanowi, że po stronie sędziów i innych urzędników, którzy administrują systemem prawnym, musi istnieć szczera i nieirracjonalna wiara, że prawo rzeczywiście kieruje się ideą sprawiedliwości zgodną z pojęciem dobra wspólnego. Prawa oparte tylko na sile dają podstawę do rebelii i oporu" (Rawls, 2001: 99).

Rorty pokazał, że możliwa jest historycystyczna interpretacja uniwersalistycznej z założenia koncepcji Rawlsa, twierdząc, że pojęcie rozumności ludów, do którego odwołuje się autor Teorii sprawiedliwości, i które stanowi niezbędny warunek do spełnienia opisanych powyżej kryteriów określających przyzwoite ludy hierarchiczne, nie ma charakteru uniwersalnego: „Gdy Rawls określa, co ma na 
myśli, stwierdzając, że dopuszczalne społeczeństwa nieliberalne nie mogą mieć nierozumnych doktryn filozoficznych ani religijnych, wyjaśnia «nierozumność» stwierdzeniem, że społeczeństwa te muszą «uznawać pewną miarę wolności sumienia i swobody myślenia, nawet jeśli wolności te nie są, ogólnie biorąc, jednakowe dla wszystkich członków społeczeństwa». Krótko mówiąc, pojęcie rozumności u Rawlsa ogranicza członkowstwo w społeczeństwie ludów do społeczności, których instytucje obejmują większość osiągnięć Zachodu ciężko wywalczonych w ciągu dwóch stuleci po epoce oświecenia” (Rorty, 2009a: 89).

Autor Przygodności, ironii i solidarności nazywa swoje stanowisko anty-antyetnocentryzmem, co jest specyficzną odpowiedzią na zarzuty o relatywizm i jednocześnie deklaracją zagorzałego demokraty, a duma z Ameryki i patriotyzm, które proponuje on zamiast „krucjaty przeciw europocentryzmowi” (USA są tu „wypustką Europy”), to duma z kraju, w którym wzrasta tolerancja i wrażliwość na cudze cierpienie. W interesującej nas kwestii największe różnice między filozofami, których poglądy referuję, dotyczą sposobu dowodzenia i perswazji; w konkluzjach nie ma już tak fundamentalnych rozbieżności.

Rorty, komentując Rawlsa, stawiał pytanie: „czy żądanie zreformowania reszty świata przez zachodnie społeczeństwa liberalne wysuwa się w imię czegoś, co nie jest tylko zachodnie - czegoś takiego, jak moralność, człowieczeństwo lub racjonalność - czy też stanowią one po prostu wyraz lojalności wobec lokalnych, zachodnich koncepcji sprawiedliwości?” (Rorty, 2009a: 87). Taką wątpliwość można jednak (pomijając chwilowo kwestię sporu kantystów z heglistami) próbować odeprzeć na sposób historycystyczny, wskazując na prace nad Powszechną Deklaracją Praw Człowieka, w których intelektualiści, pochodzący z całkowicie odmiennych kultur, ustalili wspólnie brzmienie uniwersalnego dokumentu.

Możliwość historycystycznej interpretacji koncepcji Rawlsa mogłaby wskazywać, że jego stanowisko nie jest tak dalekie od odrzucanej przez Nussbaum ze względu na etnocentryczny charakter koncepcji Rorty’ego, jak to się może z początku czytelnikowi wydawać. Rawls podkreślał jednak w swojej książce, że prawo ludów nie jest etnocentryczne (Rawls, 2001: 175) ${ }^{5}$. Sprowadzanie różnic między Rawlsem czy Nussbaum a Rortym tylko do odmiennych interpretacji jest posunięciem bardzo ryzykownym. W jakiejś mierze są to różnice nie do usunięcia.

Adam Chmielewski użył swego czasu określenia „filozoficzna wojna o prawa człowieka” (Chmielewski, 1999), wyrażając jednocześnie wątpliwości co do

5 „Musimy za każdym razem rozpoczynać w punkcie, w którym się aktualnie znajdujemy (...). Na zarzut, że taka procedura jest etnocentryczna lub po prostu zachodnia, odpowiadamy: nie, niekoniecznie. Będzie to zależało od treści prawa ludów, która zostanie przyjęta przez społeczeństwa liberalne. Obiektywność tego prawa z pewnością nie zależy od czasu, miejsca i kultury pochodzenia, lecz od tego, czy spełnia ono kryterium zależności przynależy do rozumu publicznego społeczności ludów liberalnych i przyzwoitych". 
możliwości zawarcia pokoju i zaistnienia porządku na gruncie teorii praw człowieka. Jedną zaś z przyczyn wątpliwości Chmielewskiego był esej Rorty’ego, w którym filozof w radykalnych słowach odrzucił możliwość filozoficznego uzasadnienia idei niezbywalnych praw człowieka.

Istnieje jednak pewne podejście do kwestii praw człowieka, jakie, moim zdaniem, mogłyby być pomocne jako platforma swego rodzaju porozumienia, a przynajmniej bardziej konstruktywnej rozmowy między osobami, które odmiennie traktują podstawowe zagadnienia teoretyczne, inaczej je uzasadniają i inaczej rozumieją.

Etyka i filozofia polityki uprawiane z ponadnarodowej perspektywy potrzebują wspólnego mianownika, wokół którego można budować porozumienie. Takim łącznikiem może być kwestia ekologii, rozważanie zanieczyszczenia atmosfery jako zjawiska, które zmusza nas do przemyślenia międzynarodowej współpracy, na co zwracają uwagę Singer i Nussbaum. Może to być kwestia praw człowieka (która zawiera w sobie również kwestię ochrony środowiska), akcentowana przez Rawlsa, a mniej doceniana przez Nusssbam.

W moim przekonaniu specyficznie ujęta koncepcja praw człowieka daje szansę na osiągnięcie kompromisu przez uczestników sporu przyjmujących odmienne założenia filozoficzne. W warstwie podstawowej prawa człowieka łączą różnych myślicieli, którzy się do nich odwołują. Niezależnie od tego, czy traktują je oni jako element uniwersalistycznej teorii sprawiedliwości, czy europocentrycznie, jako dorobek kultury Zachodu, różni filozofowie deklarują silne przywiązanie do idei praw człowieka. Za pomocą odpowiednio ujętej ich koncepcji można więc próbować pogodzić zwolenników oświeceniowego rozumu i wątpiących w niego myślicieli skłonnych odwoływać się raczej do ludzkich uczuć, przywiązanych do pojęcia sprawiedliwości, i zwolenników rozszerzania lojalności, uniwersalistów oraz europocentrystów itd.

Jako przykład podejścia do zagadnienia praw człowieka, które może prowadzić do kompromisu, proponuję „miękki uniwersalizm” w ujęciu Wiktora Osiatyńskiego (Osiatyński, 2011). Zakłada się w nim rozdzielenie idei uniwersalności praw człowieka i uniwersalności filozofii praw człowieka. Zgadzam się z Osiatyńskim, że upieranie się przy uniwersalności filozofii praw człowieka tworzy więcej problemów niż rozwiązuje (pod tym sformułowaniem podpisałby się pewnie i Rorty).

„Miękki uniwersalizm” umieszcza prawa człowieka w centrum wspólnych wartości, dopuszcza jednak odmienne formy wyrażania owych wartości jako powstałe na gruncie różnych kultur. Daje to szansę na uniknięcie „kulturowego imperializmu”, o który czasem są oskarżani uniwersalistycznie nastawieni myśliciele. „Przy rozpatrywaniu zarzutów kierowanych przeciw prawom człowieka należy być otwartym na włączanie w ich skład wybranych potrzeb, wartości i problemów zgłaszanych przez krytyków. Zwolennicy «miękkiego» uniwersalizmu dbają tė̇ 
o wspomaganie i emancypację grup zmarginalizowanych i pominiętych, które nie mieszczą się obecnie w obszarze rzekomo uniwersalnych praw człowieka" (Osiatyński, 2011: 287).

Wspomaganie i emancypacja marginalizowanych grup to hasło ważne dla kosmopolitów takich jak Nussbaum. Antyfundamentalistów w rodzaju Rorty'ego mogłoby przekonać, gdy miękki uniwersalista pisze: „Byliśmy tam, gdzie wy jesteście teraz, a oto co pomogło nam dojść do miejsca, w którym jesteśmy dziś. Oto jak się zmieniliśmy, a oto koszty, jakie musieliśmy w tym celu ponieść. Może chcecie skorzystać z naszych doświadczeń, oto one”. Uniwersalistę Rawlsa połączyć może $\mathrm{z}$ omawianą propozycją zdecydowany sprzeciw wobec użycia przemocy i wojny jako narzędzia zmiany. Zresztą w przypadku praw człowieka autor Teorii sprawiedliwości łagodził sposób uzasadniania, pisząc: „Nadrzędne doktryny religijne i niereligijne mogą wywodzić ideę praw człowieka z teologicznej, filozoficznej lub moralnej koncepcji natury osoby ludzkiej. Prawo ludów nie idzie tą drogą. To, co nazywam prawami człowieka, to (...) właściwy podzbiór praw posiadanych przez obywateli w liberalnych ustrojach demokratycznych lub praw członków przyzwoitego społeczeństwa hierarchicznego" (Rawls, 2001: 175).

Można wskazywać pewne elementy wspólne dla „miękkiego” i „twardego” uniwersalizmu, jak konsekwentna niezgoda na nieludzkie traktowanie oraz sprzeciw wobec wszelkiego ucisku. Konsensus w filozofii praw człowieka wydaje się jednak niemożliwy, w pełni może połączyć intelektualistów jedynie zgoda co do tego, że powinniśmy trwać przy przestrzeganiu i promowaniu praw człowieka.

\section{Literatura}

Chmielewski A. (1999). Filozoficzna wojna o prawa człowieka, review of book by Beth Singer Pragmatism, Rights and Democracy. New York

Kalbarczyk T. (2009). Wychowanie obywatelskie: między patriotyzmem a kosmopolityzmem. „Przegląd Filozoficzny” nr 1 (69)

Nussbaum M. (1996). Patriotism and Cosmopolitanizm. [W:] For Love of Country. Debating the Limits of Patriotism. Boston

Nussbaum M. (2008). W trosce o człowieczeństwo. Klasyczna obrona reformy kształcenia ogólnego. Wrocław

Osiatyński W. (2011). Prawa człowieka i ich granice. Kraków

Rawls J. (2001). Prawo ludów. Warszawa

Rorty R. (2009a). Filozofia jako polityka kulturalna. Warszawa

Rorty R. (2009b). Przygodność, Ironia, Solidarność. Warszawa

Singer P. (2006). Jeden Świat. Etyka globalizacji. Warszawa 


\section{Ethnocentrism and Universalism. How to Hold a Dialogue and Look for Foundations for Global Understanding?}

\section{summary}

The author of the paper presents some controversies in the discussion between protagonists of different standpoints towards globalization in the contemporary philosophy to show possible areas of agreements and solutions that positively influence the shape of the contemporary political philosophy. The doubts about philosophical standpoints legacy which are usually the core of the disagreement are being analyzed. The author emphasizes the issue of relativism, which is fundamental in the justice theory and cosmopolitan ideas. There is a space between contradictory standpoints for the rational ethics or theory of politics

The theories of human rights seem to be essential to engage in polemics with radical relativism as well as they offer some solutions that can constructively influence the analyzed philosophical debate. The author refers also to the concept of Wiktor Osiatyński's "soft universalism" of human rights, which can be deployed as a tool for building compromise between contradictory standpoints.

The author refers to Martha Nussbaum concepts in the first part of the paper. Her idea of global citizenship is perceived as the ethical base and also as a cosmopolitan approach towards education. The author of the paper indicates on the philosophical discussion between Nussbaum and Rotry and makes attempt to show the main points of these two contradictory standpoints. The author points out on the divergent approaches towards Kant's philosophy. He also portrays Rorty's dilemmas towards globalization, especially in the economic context. $\mathrm{He}$ explains that liberal justice theories (especially the theory of John Rawls) are free from the radical perspectives. Thus, he analyses two criteria of John Rawls's theory in order to show the framework of theory application. In this part of the paper the fundamental human rights are presented. Rorty divergent approach towards universality of Rawls's theory is being recalled. The author points out that despite of different approaches of above mentioned philosophers in the arguing and persuasion, their conclusions are not fundamentally divergent. However, at the first glance theories of Rawls, Nussbaum and Rorty can be perceived differently in the sphere of interpretation but Kalbarczyk maintains, that these contradictions can not be removed.

The analyzed discussion between above mentioned philosophers raises the doubts whether the consensus is possible to achieve on the ground of human right theories. Thus, the author of the paper indicates on the approach which can serve as a helpful setting in the discussion on the human rights. He writes that "ethics and philosophy from the supranational perspective need the common ground in order to reach consensus". He finds ecology and human rights issues as this ground, while the main concerns of this field must be worked out on the international level. The author of the paper maintains that "peculiarly concept of human rights is a chance to build compromise between different philosophical approaches". Kalbarczyk explains that despite divergent voices, philosophers declares strong commitment to the idea of human rights. Thus, he indicates on Wiktor Osiatyński's "soft universalism" as the compromise in the field of philosophical backgrounds of the human rights. Idea of human rights universality is divided from the philosophy of human rights universality. 
Human rights are the heart of the common values in the concept of "soft universalism", however different forms of values expression are permissible. Furthermore Kalbarczyk convinces the readers that " soft universalism" would meet with above mentioned philosophers approval.

The author of the paper concludes "one can indicates on the common ground for 'soft' and 'hard' universalism, as the consequence of disagreement towards inhuman treatment and the resistance to oppression. Consensus may be reached in the philosophy of human rights, when all intellectuals would agree upon the notion that all of us should obey and promote human rights". 
